\title{
The Canadian Arctic Expedition 1913-18 and Early Advances in Arctic Vertebrate Zoology
}

\author{
Kamal Khidas ${ }^{1}$ \\ (Received 4 April 2014; accepted in revised form 5 November 2014)
}

\begin{abstract}
A century ago, an international team of scientists sailed under the Canadian flag to the western Canadian Arctic, via the Bering Strait, to achieve the goals of the Canadian Arctic Expedition of 1913 - 18. This major expedition was a milestone in the history of Canada. The scientists explored a vast, unknown sea and land area that extended from the Alaskan northern coast to Bathurst Inlet in Canada, and from Meighen Island to approximately $160-200 \mathrm{~km}$ inland from the continental coasts. This area had never been explored by an expedition before, and many parts of it had never been visited (except, presumably, by Inuit and their ancestors). The expedition resulted in a remarkable harvest of terrestrial and marine plants and animals, and associated data. The scientists furthered geographic and scientific knowledge of the Arctic and published 74 reports in various scientific fields, yet none of these addressed vertebrate zoology. The present report attempts to make up for this deficiency. Overall, the CAE collected and preserved 2084 vertebrate specimens and inventoried 139 species, which together fairly depicted the Arctic vertebrate community. Almost all specimens are preserved at the Canadian Museum of Nature. They significantly supplemented the rather meagre vertebrate collections of the Museum of those times and have since prompted the continuing development of these collections.
\end{abstract}

Key words: Canadian Arctic Expedition; Arctic; Arctic vertebrates; Canadian Museum of Nature; vertebrate collections; Vilhjalmur Stefansson; Rudolph Martin Anderson

RÉSUMÉ. Il y a un siècle, une équipe internationale de scientifiques a navigué sous pavillon canadien vers l'ouest de l'Arctique canadien en passant par le détroit de Béring pour atteindre les objectifs de l'Expédition canadienne dans l'Arctique de 1913-1918. Cette expédition s'est avérée un jalon important de l'histoire du Canada. Les scientifiques ont exploré une vaste région mal connue de mer et de terre s'étendant de la côte nord de l'Alaska jusqu'à Bathurst Inlet, au Canada, et de l'île Meighen jusqu'à environ 160 à $200 \mathrm{~km}$ à l'intérieur des terres continentales. Cette région n'avait jamais été explorée auparavant par une seule expédition; une bonne partie était même totalement inconnue (exception faite, vraisemblablement, des Inuits et de leurs ancêtres). Une moisson impressionnante de plantes et d'animaux terrestres et marins, et de données connexes a été obtenue grâce à cette expédition. Cette expédition a également donné lieu à l'approfondissement des connaissances géographiques et scientifiques inhérentes à l'Arctique de même qu'à la publication de 74 rapports relevant de plusieurs disciplines scientifiques. Pourtant, les vertébrés n'ont fait l'objet d'aucun de ces rapports. Le présent rapport tente de pallier cette carence. Au total, 2084 spécimens de vertébrés ont été recueillis et préservés, et 139 espèces inventoriées. Cet échantillon était représentatif de la communauté des vertébrés de l'Arctique. Les spécimens sont conservés en majorité au Musée canadien de la nature. À l'époque, leur incorporation aux collections de vertébrés du Musée, qui en étaient alors à leurs premiers balbutiements, a constitué un ajout décisif et a enclenché un véritable développement de ces collections.

Mots clés : Expédition canadienne dans l'Arctique; Arctique; vertébrés arctiques; Musée canadien de la nature; collections de vertébrés; Vilhjalmur Stefansson; Rudolph Martin Anderson

Révisé pour la revue Arctic par Nicole Giguère.

\section{INTRODUCTION}

Geographical discoveries in the North American Arctic and surrounding areas have prompted numerous expeditions since the 16th century (Levere, 2004). Commerce, search for prosperity, and sovereignty issues were probably the driving motives (Mirsky, 1970; Diubaldo, 1978; Schledermann, 2003; Levere, 2004), but these explorations resulted in the discovery and the mapping of lands and islands.
Scientific investigations have almost always constituted a major component of Arctic expeditions as well (Levere, 2004). Extensive knowledge was garnered on various topics, including astronomy, geomagnetism, oceanography, hydrography, meteorology, botany, zoology, and ethnology. Natural history in particular has benefited, largely from expeditions since the late 18th century. Explorers, including Samuel Hearne, John Ross, William E. Parry, John Franklin, John Rae, and George S. Nares in the 19th century and

\footnotetext{
${ }^{1}$ Canadian Museum of Nature, PO Box 3443, Station D, Ottawa, Ontario K1P 6P4, Canada; kkhidas@mus-nature.ca

(C) Her Majesty the Queen in Right of Canada. Administered by the Arctic Institute of North America
} 
Robert E. Peary in the early 20th century, visited several parts of the North American Arctic and surrounding areas, collecting numerous animal and plant specimens (Levere, 1988, 2004). Arctic geography and natural history, however, remained poorly known at the turn of the 20th century. Maps were still incomplete, and the geographical information was fragmentary. The inventory of Arctic wildlife listing the different species and their distribution range was very partial, and museum collections were poor in Arctic specimens (Clarke, 1954). Finding new lands, collecting specimens, and gathering ethnological data on the Inuit people constituted strong motives for further expeditions in the early 20th century. These incentives paved the way for the famous Canadian Arctic Expedition (CAE) of $1913-18$.

The two main objectives of the CAE were (1) to explore an unknown area of sea and land nearly 2.6 million $\mathrm{km}^{2}$ in the North American Arctic and (2) to amass scientific information, including collections of natural history specimens and cultural artefacts (Naval Service, 1915). The fieldwork was to be undertaken in three years, as first decreed by the Privy Council of Canada on 22 February 1913 (Boudreau, 1913). Fifteen scientists were selected from eight countries, including Canada, to accomplish the CAE's ambitious mission (Stefansson, 1919). They sailed to the western Arctic via the Bering Strait. Two parties were created. A northern party, led by Vilhjalmur Stefansson, also executive chief of the CAE, aimed to explore the Beaufort Sea and adjacent waters and lands and to garner anthropological, geological, topographic, botanical, and zoological information. Stefansson was one of the most renowned Arctic explorers. He had previously visited the Arctic in the Anglo-American Polar Expedition of 1906-07 and led the StefanssonAnderson overland expedition of 1908-12 to the central Arctic coast (Stefansson, 1913). A southern party, under the direction of Rudolph M. Anderson, also second-in-command of the CAE, aimed primarily to investigate and map the copper-bearing and associated rocks in the northwesternmost parts of mainland Canada and to complete scientific and anthropological investigations (Naval Service, 1915; Anderson, 1917, 1918; Zaslow, 1975). The government of Canada considered the northern party's mission to be crucial (Desbarats, 1913). As part of the important objectives of the CAE, the parties were to complete an inventory of zoological species and make as comprehensive and representative a collection of specimens and associated field data as it was possible to obtain. The CAE would also supply specimens to the museum of the Geological Survey of Canada (GSC) and the scientific collections of the Department of Naval Service in Ottawa (Brock, 1913).

A century later, interest is growing in Arctic politics and commerce and in the Arctic environment. The CAE remains a milestone in Canada's history (Diubaldo, 1978; Levere, 2004; Jenness, 2011). It garnered noteworthy knowledge about the Arctic environment, and its members produced several reports in biology, geology, and anthropology, yet none has ever been published on any of the fish, birds, or mammals. The present report revisits the CAE's achievements and attempts to make up for this deficiency by providing the first comprehensive account of those three zoological groups. The specimens are housed at the Natural Heritage Campus of the Canadian Museum of Nature $(\mathrm{CMN})$ in Gatineau, Quebec. This account is based on a review of these specimens, the associated documentation and data, and the numerous field notes archived at the CMN.

\section{COLLECTION OF VERTEBRATE SPECIMENS}

The CAE collected 2084 fish, bird, and mammal specimens and inventoried 139 species (Tables 1, 2, and 3). The taxonomic nomenclature used in Tables 1 to 3 follows Froese and Pauly (2015), Page et al. (2013), and the World Register of Marine Species (WoRMS Editorial Board, 2015) for fishes; the American Ornithologists' Union (2014) for birds; and Wilson and Reeder (2005) for mammals. Most of the specimens were collected during the summers, but many mammals (15 species; 97 specimens) and a few birds (five species; eight specimens) were collected during winter as well. No fish were collected during winter. The fish inventory was completed in 1916 (no date specified), that of the birds in October 1917, and that of the mammals in December 1917.

Anderson and Fritz Johansen together collected 79.5\% ( $45 \%$ and $34.5 \%$, respectively) of the total specimens gathered during the first three years, from summer 1913 to summer 1916. Anderson was the GSC's zoologist in Ottawa. He obtained a $\mathrm{PhD}$ in systematic zoology and comparative anatomy in 1906 from the State University of Iowa (Soper, 1962; Zaslow, 1975), where Stefansson had also earned a degree in 1903. Anderson was attached to the aforementioned expedition of $1908-12$ as a naturalist. He worked for the American Museum of Natural History (AMNH) during those years and for the GSC from 1913 to 1946. He was appointed Chief of the Biology Division of the National Museum of Canada in 1920. Johansen, marine biologist, entomologist, and botanist for the CAE, served as zoologist and naturalist on the Danish Expedition to Greenland from 1906 to 1908. Later, he worked for the U.S. Department of Agriculture, and in 1913, he was hired by the Department of Naval Service to serve with the CAE. In the 1920s, he was employed by the Canadian Department of Marine and Fisheries as an oceanographer. John Hadley, a professional sailor and a ship officer with the CAE, also was active in collecting a number of birds, mammals, and fish $(7 \%$ of the specimens). George H. Wilkins, the official photographer and cinematographer of the CAE, collected birds and mammals ( $6 \%$ of the specimens) in and around Cape Kellett on Banks Island. Peter Bernard, former owner and now the Captain of the CAE schooner Mary Sachs, also collected birds and mammals (about 3\% of the specimens) at Cape Kellett. 
Fish

Slightly more than 700 fish were collected. After the southern party completed its mission in July 1916, the specimens were sent to the Canadian Fisheries Museum (Department of Naval Service) in Ottawa for safekeeping; however, when the museum was shut down in 1918, the fish collection was transferred to the Victoria Memorial Museum (GSC), now the CMN, in Ottawa (Cook et al., 2010). Currently, 698 fish are preserved in two museums: of these, 689 are at the $\mathrm{CMN}$, and the remainder are at the AMNH (Table 1).

Eight orders, 26 genera, and 34 species of fish were inventoried (two species at least were unidentified). Most of the specimens belong to the Scorpaneiformes and Gasterosteiformes ( $90 \%$ of the total number of specimens), the latter order being represented by a single species, the ninespine stickleback (Table 1). The ninespine stickleback and fourhorn sculpin dominated the specimens collected, representing altogether $75.6 \%$ of the catch, but the majority of species were represented by at most four specimens (Table 1). In addition to the species listed in Table 1, Johansen mentioned, in an unpublished manuscript, nine other species: broad whitefish (Coregonus nasus), sardine cisco (Coregonus sardinella), saffron cod (Eleginus gracilis), fourline snakeblenny (Eumesogrammus praecisus), fish doctor (Gymnelus viridis), polar eelpout (Lycodes turneri), hamecon (Artediellus scaber), Artedius sp. (possibly the Arctic hookear sculpin, Artediellus uncinatus), twohorn sculpin (Icelus bicornis), and Arctic flounder (Liopsetta glacialis). None, however, is preserved in a museum. Walters (1953) mentioned that the CMN had two disintegrated fish doctors, but these specimens no longer exist at the CMN. Walters also mentioned that the AMNH had three hamecon specimens, but none seems to have been catalogued since that time.

The specimens were collected along the northern coastline of continental North America, on the Alaskan, Mackenzie, and Amundsen shelves, mostly in Bernard Harbour and vicinity, Nunavut (71.5\% of the specimens), and at Martin Point, Alaska (15.7\%) (Fig. 1). Except for two freshwater fish, the Arctic grayling and lake trout, all are marine species. Compared to most Arctic marine fishes associated with benthic habitats (Mueter et al., 2013), two-thirds (67.6\%) of the species reported by the CAE are demersal (near-bottom dwellers). The fourline snakeblenny, Arctic grayling, Arctic char, lake trout, ninespine stickleback, and Pacific sand lance are benthopelagic (species that float or swim just over the floor of the sea); the Pacific herring, sardine cisco, Arctic cisco, and capelin are pelagic-neritic (inhabiting shallow coastal waters over the continental shelf); and the polar cod is bathypelagic (occurring in the mid-waters below the level of light penetration, which, depending on the authors, may lie between $900 \mathrm{~m}$ and $4000 \mathrm{~m}$ ).

Seventy-eight percent of the fishes reported by the CAE, including those mentioned in Johansen's unpublished report, are true Arctic species, i.e., those that occur either
TABLE 1. Fishes collected by the Canadian Arctic Expedition 1913 - 18. The percentages in parentheses indicate the proportion of the total fish collection represented by specimens of each order. Numbers indicate specimens preserved at the Canadian Museum of Nature and, in parentheses, at the American Museum of Natural History in New York. An asterisk indicates a true Arctic species (after Reshetnikov, 2004).

\begin{tabular}{|c|c|}
\hline Species & Number of specimen \\
\hline \multicolumn{2}{|l|}{ Order Clupeiformes $(0.1 \%)$} \\
\hline \multicolumn{2}{|l|}{ Pacific herring (Clupea pallasii) } \\
\hline \multicolumn{2}{|l|}{ Order Salmoniformes $(6.8 \%)$} \\
\hline \multicolumn{2}{|l|}{ Arctic cisco (Coregonus autumnalis)* } \\
\hline \multicolumn{2}{|l|}{ Sheefish (Stenodus leucichthys)* } \\
\hline \multicolumn{2}{|l|}{ Arctic grayling (Thymallus arcticus)* } \\
\hline Arctic char (Salvelinus alpinus)* & \\
\hline \multicolumn{2}{|l|}{ Lake trout (Salvelinus namaycush) } \\
\hline \multicolumn{2}{|l|}{ Order Osmeriformes $(0.1 \%)$} \\
\hline Capelin (Mallotus villosus) & 0 \\
\hline \multicolumn{2}{|l|}{ Order Gadiformes $(2.3 \%)$} \\
\hline \multicolumn{2}{|l|}{ Polar cod (Arctogadus glacialis)* } \\
\hline \multicolumn{2}{|l|}{ Arctic cod (Boreogadus saida)* } \\
\hline \multicolumn{2}{|l|}{ Greenland cod (Gadus ogac)* } \\
\hline \multicolumn{2}{|l|}{ Order Gasterosteiformes $(37.8 \%)$} \\
\hline Ninespine stickleback (Pungitius pungitius)* & 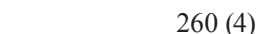 \\
\hline \multicolumn{2}{|l|}{ Order Scorpaeniformes $(52.2 \%)$} \\
\hline \multicolumn{2}{|l|}{ Whitespotted greenling (Hexagrammos stelleri) } \\
\hline \multicolumn{2}{|l|}{ Threaded sculpin (Gymnocanthus pistilliger)* } \\
\hline \multicolumn{2}{|l|}{ Arctic staghorn sculpin (Gymnocanthus tricuspis)* } \\
\hline \multicolumn{2}{|l|}{ Myoxocephalus sp. } \\
\hline \multicolumn{2}{|l|}{ Fourhorn sculpin (Myoxocephalus quadricornis)* } \\
\hline \multicolumn{2}{|l|}{ Arctic sculpin (Myoxocephalus scorpioides)* } \\
\hline \multicolumn{2}{|l|}{ Shorthorn sculpin (Myoxocephalus scorpius) } \\
\hline \multicolumn{2}{|l|}{ Ribbed sculpin (Triglops pingelii)* } \\
\hline \multicolumn{2}{|l|}{ Tubenose poacher (Pallasina barbata) } \\
\hline \multicolumn{2}{|l|}{ Liparis sp. } \\
\hline \multicolumn{2}{|l|}{ Gelatinous snailfish (Liparis fabricii)* } \\
\hline \multicolumn{2}{|l|}{ Kelp snailfish (Liparis tunicatus)* } \\
\hline \multicolumn{2}{|l|}{ Order Perciformes $(0.3 \%)$} \\
\hline \multicolumn{2}{|l|}{ Pacific sand lance (Ammodytes hexapterus) } \\
\hline \multicolumn{2}{|l|}{ Order Pleuronectiformes $(0.3 \%)$} \\
\hline Starry flounder (Platichthys stellatus)* & \\
\hline Total number of specimens & \\
\hline
\end{tabular}

solely in waters of High Arctic latitudes or in both High Arctic waters and, to a lesser extent, in boreal waters at more southerly latitudes (Reshetnikov, 2004).

The CAE reported only 34 species, compared to the 84 currently reported in the Canadian Beaufort Sea-Amundsen Gulf area (Mueter et al., 2013), where the southern party focused its fish survey. This low number was probably due mainly to sea ice conditions and sea depth, two factors that have long constrained surveys of Arctic fishes (Mueter et al., 2013). Thick sea ice constitutes a major hindrance to sea explorations, which may practicably be completed only during the short Arctic summer and only in places where the ice has melted. The area actually probed by the CAE consists of relatively flat, shallow plains with average depth of 35 to $200 \mathrm{~m}$ and has little direct exchange with other ocean systems (Mathias, 2013). Consequently, the primary productivity and fish community richness there are relatively low compared to the rest of the Beaufort Sea (Mathias, 2013). Further, the Arctic ichthyofauna varied over time with environmental changes (Mueter et al., 2013). Climate 


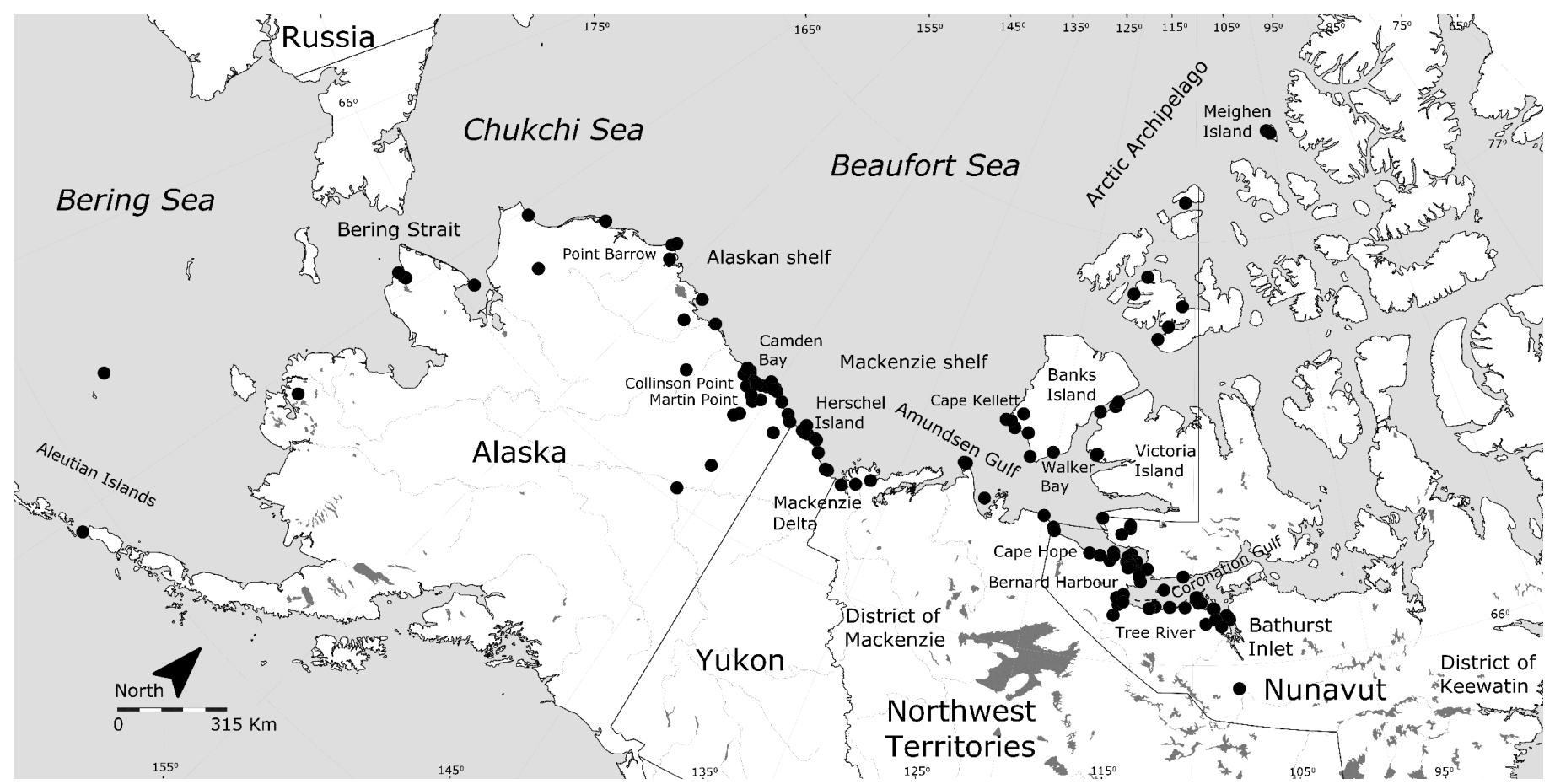

FIG. 1. Location of sites in Alaska and Canada where the Canadian Arctic Expedition 1913-18 collected vertebrates.

fluctuations would produce changes in this fauna, with the Arctic possibly undergoing increasing influences from the northern Pacific and Atlantic Oceans (Norcross et al., 2010; Mueter et al., 2013). It is possible then that the number of fish species in the Beaufort Sea was actually slightly lower in the early 20th century, when the CAE took place, than at present. As to the number of specimens collected, the yield should be density-dependent at a given time and place, with the nets very likely catching more individuals of abundant species (such as the ninespine stickleback and fourhorn sculpin) that are numerically important in nearshore areas.

\section{Birds}

In total, 854 bird specimens were collected, and 11 orders, 53 genera, and 79 species were inventoried, the majority of which were either Charadriiformes or Anseriformes (58\% of the specimens) (Table 2). The number of Common Eiders was the highest, representing 7.5\% of the specimens collected. Thirty-six specimens were obtained from Joseph F. Bernard, an itinerant trader, not a member of the CAE.

The specimens were collected mainly around Bernard Harbour $(24.7 \%$ of the specimens), at Collinson Point (13.6\%) in Alaska, and at Cape Kellett $(10 \%)$ on Banks Island. In June 1916, Stefansson collected two sets of eggs (one Brant and one Ivory Gull) on a newly discovered island, later named Meighen Island, and these were the most northerly vertebrates collected from the expedition. The species inventoried occurred in a wide variety of habitat types in the western Arctic. The habitat of $47.4 \%$ of them, including almost all the Anseriformes and
Charadriiformes, Gaviiformes, Podicipediformes, and Gruiformes, consists of a complex landscape of bogs, marshes, lakes, ponds, and streams scattered across tundra on the coasts and inland. For many other species (34\%), including the Galliformes, Accipitriformes, Falconiformes, and several of the Charadriiformes and Passeriformes, the habitat consists of open tundra interspersed with woody vegetation. Other birds (10\%) are marine species, including the Procellariiformes, which are encountered mostly in the open ocean, and other species such as the Common Eider, Thayer's Gull, Glaucous Gull, Thick-billed Murre, and Black Guillemot, which are found on Arctic coasts. The Ivory Gull is linked to pack ice. The Great Horned Owl, Northern Hawk Owl, Gray Jay, Orange-crowned Warbler, Fox Sparrow, and Dark-eyed Junco typically occur in forests and woodlands. They were collected at the northernmost edge of the boreal biome, except for the Orange-crowned Warbler and Dark-eyed Junco that were collected in the remote Coronation Gulf area, in the tundra.

Only the ptarmigans, Ivory Gull, Black Guillemot, Snowy Owl, Gyrfalcon, Common Raven, and Hoary Redpoll $(10 \%$ of the bird species inventoried by the CAE) remain over parts of the western Arctic throughout the winter. However, $68 \%$ of the CAE birds are true Arctic species, defined as those with more than $90 \%$ of the population or breeding range lying within the Arctic in the summer (Ganter and Gaston, 2013). Nine other species breed only locally in the Arctic: Horned Grebe, Leach's Storm-petrel, Swainson's Hawk, Great Horned Owl, Northern Hawk Owl, Gray Jay, Palm Warbler, Orange-crowned Warbler, and Dark-eyed Junco. The Northern Fulmar (collected at Cape Kellett), Swainson's Hawk (collected at Bernard Harbour), 
TABLE 2. Birds collected by the Canadian Arctic Expedition 1913-18 and preserved at the Canadian Museum of Nature. The percentages in parentheses indicate the proportion of the total bird collection represented by specimens of each order. An asterisk indicates a true Arctic species (after Ganter and Gaston, 2013).

\begin{tabular}{|c|c|c|c|}
\hline \multirow{2}{*}{$\begin{array}{l}\text { Species } \\
\text { Order Anseriformes }(24 \%)\end{array}$} & Number of specimens & \multirow{2}{*}{$\begin{array}{l}\text { Species } \\
\text { Stilt Sandpiper (Calidris himantopus)* }\end{array}$} & Number of specimens \\
\hline & & & 6 \\
\hline Greater White-fronted Goose (Anser albifrons)* & 3 & Buff-breasted Sandpiper (Calidris subruficollis)* & 2 \\
\hline Snow Goose (Chen caerulescens)* & 4 & Red-necked Phalarope (Phalaropus lobatus)* & 2 \\
\hline Brant (Branta bernicla)* & 16 & Red Phalarope (Phalaropus fulicarius)* & 21 \\
\hline Cackling Goose (Branta hutchinsii) & 6 & Black-legged Kittiwake (Rissa tridactyla)* & 8 \\
\hline Tundra Swan (Cygnus columbianus)* & 1 & Ivory Gull (Pagophila eburnea)* & 1 \\
\hline Northern Pintail (Anas acuta) & 12 & Sabine's Gull (Xema sabini)* & 24 \\
\hline Steller's Eider (Polysticta stelleri)* & 8 & Mew Gull (Larus canus) & 1 \\
\hline Spectacled Eider (Somateria fischeri)* & 12 & Herring Gull (Larus argentatus) & 2 \\
\hline King Eider (Somateria spectabilis)* & 42 & Thayer's Gull (Larus thayeri)* & 12 \\
\hline Common Eider (Somateria mollissima)* & 64 & Glaucous Gull (Larus hyperboreus)* & 23 \\
\hline Harlequin Duck (Histrionicus histrionicus) & 4 & Arctic Tern (Sterna paradisaea)* & 13 \\
\hline Surf Scoter (Melanitta perspicillata) & 1 & Pomarine Jaeger (Stercorarius pomarinus)* & 20 \\
\hline White-winged Scoter (Melanitta fusca) & 1 & Parasitic Jaeger (Stercorarius parasiticus)* & 7 \\
\hline Long-tailed Duck (Clangula hyemalis)* & 29 & Long-tailed Jaeger (Stercorarius longicaudus)* & 9 \\
\hline Red-breasted Merganser (Mergus serrator)* & 2 & Thick-billed Murre (Uria lomvia)* & 2 \\
\hline Order Galliformes $(9.4 \%)$ & & Black Guillemot (Cepphus grylle)* & 3 \\
\hline Willow Ptarmigan (Lagopus lagopus)* & 42 & Order Strigiformes $(4.8 \%)$ & \\
\hline Rock Ptarmigan (Lagopus muta)* & 38 & Great Horned Owl (Bubo virginianus) & 1 \\
\hline Order Gaviiformes $(9 \%)$ & & Snowy Owl (Bubo scandiacus)* & 31 \\
\hline Red-throated Loon (Gavia stellata)* & 22 & Northern Hawk Owl (Surnia ulula) & 2 \\
\hline Pacific Loon (Gavia pacifica)* & 34 & Short-eared Owl (Asio flammeus) & 7 \\
\hline Yellow-billed Loon (Gavia adamsii)* & 21 & Order Falconiformes $(1.4 \%)$ & \\
\hline Order Podicipediformes $(0.1 \%)$ & & Gyrfalcon (Falco rusticolus)* & 5 \\
\hline Horned Grebe (Podiceps auritus) & 1 & Peregrine Falcon (Falco peregrinus) & 7 \\
\hline Order Procellariiformes $(0.2 \%)$ & & Order Passeriformes $(13.8 \%)$ & \\
\hline Northern Fulmar (Fulmarus glacialis)* & 1 & Northern Shrike (Lanius excubitor) & 2 \\
\hline Leach's Storm-petrel (Oceanodroma leucorhoa) & 1 & Gray Jay (Perisoreus canadensis) & 5 \\
\hline Order Accipitriformes $(2.5 \%)$ & & Common Raven (Corvus corax) & 4 \\
\hline Swainson's Hawk (Buteo swainsoni) & 1 & Horned Lark (Eremophila alpestris)* & 22 \\
\hline Rough-legged Hawk (Buteo lagopus)* & 20 & American Robin (Turdus migratorius) & 2 \\
\hline Order Gruiformes $(0.6 \%)$ & & Eastern Yellow Wagtail (Motacilla tschutschensis) & 3 \\
\hline Sandhill Crane (Grus canadensis) & 5 & American Pipit (Anthus rubescens)* & 6 \\
\hline Order Charadriiformes $(34.2 \%)$ & & Lapland Longspur (Calcarius lapponicus)* & 36 \\
\hline Black-bellied Plover (Pluvialis squatarola)* & 16 & Snow Bunting (Plectrophenax nivalis)* & 23 \\
\hline American Golden-plover (Pluvialis dominica)* & 11 & Northern Waterthrush (Parkesia noveboracensis) & 1 \\
\hline Semipalmated Plover (Charadrius semipalmatus)* & 17 & Orange-crowned Warbler (Oreothlypis celata) & 1 \\
\hline Whimbrel (Numenius phaeopus)* & 2 & Palm Warbler (Setophaga palmarum) & 1 \\
\hline Ruddy Turnstone (Arenaria interpres)* & 11 & American Tree Sparrow (Spizella arborea)* & 2 \\
\hline Sanderling (Calidris alba)* & 8 & Savannah Sparrow (Passerculus sandwichensis)* & 1 \\
\hline Semipalmated Sandpiper (Calidris pusilla)* & 10 & Fox Sparrow (Passerella iliaca) & 3 \\
\hline Western Sandpiper (Calidris mauri)* & 1 & Dark-eyed Junco (Junco hyemalis) & 2 \\
\hline White-rumped Sandpiper (Calidris fuscicollis)* & 3 & Common Redpoll (Acanthis flammea)* & 1 \\
\hline Baird's Sandpiper (Calidris bairdii)* & 44 & Hoary Redpoll (Acanthis hornemanni)* & 4 \\
\hline Pectoral Sandpiper (Calidris melanotos)* & 10 & & \\
\hline Dunlin (Calidris alpina)* & 3 & Total number of specimens & 855 \\
\hline
\end{tabular}

Orange-crowned Warbler (collected at Cape Hope, Nunavut), Palm Warbler (collected at Bernard Harbour), and Dark-eyed Junco (collected at Tree River and at Bernard Harbour) were collected from localities that lie far outside the species' known distribution ranges (Godfrey, 1986), indicating rare, stranded individuals in the far Arctic.

The relatively low number of bird species inventoried by the CAE, 79 vs. 123 identified to date in the western Arctic (Godfrey, 1986; Ganter and Gaston, 2013), could be due to the relatively small area prospected. Several species that occur in the western Arctic, even in abundance in some parts, such as the Western Sandpiper (Calidris mauri), Northern Wheatear (Oenanthe oenanthe), and Wilson's Warbler (Cardellina pusilla), were absent or rarer in the areas where the CAE frequently operated. The collecting method used by the CAE also would account for this low number of species (see comments in the Mammals section below).

\section{Mammals}

In total, 531 mammal specimens were collected, and five orders (mostly carnivores and rodents), 22 genera, and 26 species were inventoried (Table 3). The Arctic fox, northern collared lemming, caribou, and Arctic ground squirrel comprised $60.7 \%$ of the total number of specimens collected.

The majority of the specimens were collected around Bernard Harbour (29\% of the specimens), at Cape Kellett and the vicinity (21.4\%), and at Collinson Point (10\%). The species were found in the whole array of habitats that occur 
in the Arctic. Most of them are terrestrial, being either eclectic in their habitat requirements, like the deer mouse, wolf, and brown bear (35\% of the species inventoried) or favouring open or shrubby tundra (23\%), like the northern collared lemming and tundra vole, or aquatic habitats (the muskrat and American mink). The deer mouse was collected on Herschel Island, outside the species' known range, which extends from the northern tree line in Alaska and Canada southward to central Mexico. The red squirrel, snowshoe hare, and Canada lynx typically occur in the boreal forest; they were collected at the northern edge of the boreal biome in the Mackenzie delta and vicinity. Marine mammals included the polar bear, walrus, bearded seal, and ringed seal. The walrus and bearded seal prefer shallow Arctic waters for feeding, in combination with areas made up of broken pack ice; the polar bear and ringed seal are linked to pack ice, the latter species being the main prey of the former.

Of the species inventoried, $69 \%$ are true Arctic mammals, that is, those that are almost entirely confined to the Arctic, including the northern collared lemming, Arctic hare, Arctic fox, and muskox; endemic marine species, such as the polar bear, walrus, bearded seal, and ringed seal; and those that currently have a wider distribution range that includes the adjacent boreal biome, but which were linked to a tundra refugium during the last glacial age (Reid et al., 2013).

The CAE inventoried mammals of various forms, as expressed by the decimal logarithm of their average weight in grams (Fig. 2). The CAE completed a fair inventory of the small, medium, and large mammals, on average weighing from $22 \mathrm{~g}$, e.g., for the northern red-backed vole, to $660 \mathrm{~kg}$ for the walrus (logarithm of the weight ranging from 1.3 to 5.8). However, micromammals, including Sorex species (weight $<7.5 \mathrm{~g}$ ) were undersampled. No cetacean species were collected (logarithm of the weight ranging from 6 to 9) although several of them did occur in the areas visited, such as beluga (Delphinapterus leucas), bowhead whale (Balaena mysticetus), and grey whale (Eschrichtius robustus).

The CAE inventoried 26 of the 62 terrestrial and marine mammal species identified to date in the western Arctic (Naughton, 2012; Reid et al., 2013). Several mammal species of this part of the Arctic, such as the Alaska marmot (Marmota broweri), tundra vole (Microtus xanthognathus), and spotted seal (Phoca largha), were in fact absent or rare in the area that was extensively prospected by the CAE. Another reason that would account for the somewhat insufficient sampling of the mammals and the birds was that the CAE primarily used firearms to collect specimens. The CAE did not seem to have set up any specific, exhaustive sampling approach, but proceeded randomly. Complete qualitative and quantitative inventories require appropriate sampling designs, as well as collecting methods adapted to the species or the group of species of interest, such as shooting for some species, and the use of various types of traps or nets for others. Shooting, however, allows the collector to

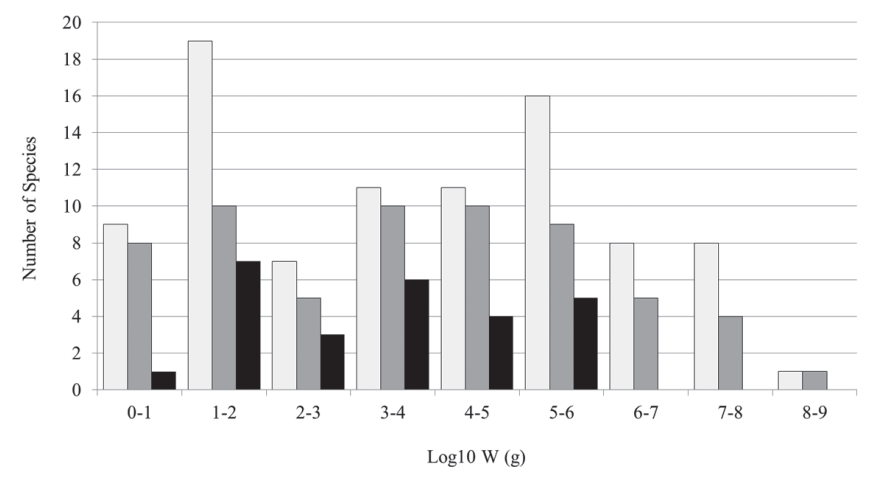

FIG. 2. Distribution of the diverse forms of Arctic mammals (expressed by the decimal logarithm of each weight range in grams). Bars represent the number of species in each weight range for North American Arctic mammals (light bars), western Arctic mammals (grey bars), and mammals collected by the Canadian Arctic Expedition 1913-18 (black bars).

get only relatively conspicuous individuals of a certain size category, such as the eiders, ptarmigans, loons, northern collared lemming, Arctic fox, and caribou, and, depending upon the skills of the shooter, those that are motionless or moving slowly when encountered. This method of collecting thus places several limitations on the physical inventory of both very small species (including shrews and many small Passeriformes) and large-bodied species (including whales).

\section{CONCLUSION}

The Canadian Arctic Expedition 1913-18 was the most comprehensive Arctic expedition of its time (Bartlett and Hale, 1916; Noice, 1924; Mirsky, 1970; Zaslow, 1975; Diubaldo, 1978; Jenness, 2011). The scientists came back home with achievements that brought them worldwide acclaim (Diubaldo, 1978). They explored an area that encompassed mostly the Beaufort Sea, Amundsen and Coronation Gulfs, the western edge of the Canadian Arctic Archipelago, and associated coastlines. They discovered new lands, mapped ca. $260000 \mathrm{~km}^{2}$ of sea and land, obtained more accurate geographical coordinates of known lands, and collected several thousands of natural history specimens, cultural objects, minerals, sound recordings of Inuit songs, and photographs (Anderson, 1918; Naval Service, 1919). Johansen amassed an impressive collection of land, marine, and freshwater invertebrates and completed a full inventory of the flora around Bernard Harbour (Anderson, 1918). Eight new genera, 93 new species, and five new subspecies and varieties of insects and other invertebrates were described from the material he collected (Hewitt, 1920). Wilkins made thousands of photographs of the flora and fauna (Anderson, 1918). Botanical and zoological specimens were collected in localities never reported before and spanned almost all known taxonomic groups (Anderson, 1918). Many other specimens may have been lost over the course of the journey, shipping, and transfers. 
TABLE 3. Mammals collected by the Canadian Arctic Expedition 1913-18 and preserved at the Canadian Museum of Nature. The percentages in parentheses indicate the proportion of the total mammal collection represented by specimens of each order. An asterisk indicates true Arctic species (after Reid et al., 2013).

\begin{tabular}{lr}
\hline \hline Species & Number of specimens \\
\hline Order Rodentia (32\%) & \\
Red squirrel (Tamiasciurus hudsonicus) & 1 \\
Arctic ground squirrel (Spermophilus parryii)* & 51 \\
Northern collared lemming (Dicrostonyx groenlandicus)* & 71 \\
Nearctic brown lemming (Lemmus trimucronatus)* & 16 \\
Tundra vole (Microtus oeconomus)* & 24 \\
Northern red-backed vole (Myodes rutilus) & 4 \\
Muskrat (Ondatra zibethicus) & 2 \\
Deer mouse (Peromyscus maniculatus) & 1 \\
Order Lagomorpha (5.4\%) & \\
Arctic hare (Lepus arcticus)* & 26 \\
Snowshoe hare (Lepus americanus) & 3 \\
Order Soricomorpha (0.2\%) & \\
Tundra shrew (Sorex tundrensis)* & 1 \\
Order Carnivora (50.5\%) & 2 \\
Canada lynx (Lynx canadensis) & 15 \\
Gray wolf (Canis lupus)* & 145 \\
Arctic fox (Vulpes lagopus)* & 5 \\
Red fox (Vulpes vulpes) & 8 \\
Brown bear (Ursus arctos)* & 32 \\
Polar bear (Ursus maritimus)* & 1 \\
Walrus (Odobenus rosmarus)* & 9 \\
Bearded seal (Erignathus barbatus)* & 13 \\
Ringed seal (Pusa hispida)* & 16 \\
Wolverine (Gulo gulo)* & 20 \\
Ermine (Mustela erminea)* & 1 \\
Least weasel (Mustela nivalis)* & 1 \\
American mink (Neovison vison) & 531 \\
Order Artiodactyla (11.9\%) & 57 \\
Caribou (Rangifer tarandus)* & \\
Muskox (Ovibos moschatus)* & \\
Total number of specimens & \\
\hline \hline & \\
\hline \hline
\end{tabular}

In regard to Arctic vertebrate zoology, the CAE completed one of the most comprehensive inventories. Anderson and Johansen, the two zoologists of the expedition, completed the bulk of the survey, which inventoried 139 fish, bird, and mammal species and collected 2084 specimens. Four new mammal subspecies were described from the material collected by the CAE: Lepus arcticus andersoni (Nelson, 1934), Phoca (Pusa) hispida beaufortiana (Anderson, 1942), Canis lupus bernardi, and C. lupus mackenzii (Anderson, 1943). No other new taxons were described from this vertebrate material. The location of the sites where the CAE parties established their quarters (i.e., Collinson Point, Bernard Harbour, and Cape Kellett) determined largely the results of the collecting endeavours. The specimens mostly originated from the Alaskan and Mackenzie shelves in Amundsen and Coronation Gulfs, primarily alongside the Alaskan and Canadian seacoasts. Soon after crossing the Bering Strait in midsummer 1913, the CAE's sailing vessels experienced poor navigation conditions as threatening ice floes (Naval Service, 1915; Anderson, 1917) forced the members of the southern party to seek a shelter in the North Slope Borough area in Alaska (Naval Service, 1916). While wintering at Collinson Point, Alaska, waiting for more clement weather conditions to resume their route to the Canadian territory, the southern party's members dedicated a large part of their time to collecting scientific data (Naval Service, 1916; Anderson, 1917), chiefly in the area of Camden Bay. In the Canadian territory, they collected specimens mostly from the Dolphin and Union Strait and the Coronation Gulf, chiefly around Bernard Harbour where this party had established its headquarters, from which they spread out for field work (Anderson, 1917; Naval Service, 1917). The majority of specimens collected by the northern party (mostly birds) originated from the vicinity of Cape Kellett on Banks Island, and to a lesser extent from Walker Bay on Victoria Island. The CAE made observations on and collected specimens of nine new fish species that had not been recorded previously in the western North American Arctic: polar cod, Greenland cod, Arctic sculpin, ribbed sculpin, tubenose poacher, saffron cod, fourline snakeblenny, hamecon, and twohorn sculpin (Walters, 1953, 1955). Moreover, the expedition determined the northern limits in the area of several fish, bird, and mammal species that previously had not been ascertained beyond the continental coasts (Macoun and Macoun, 1909; Anderson, 1913; Walters, 1955). For the first time in the western Arctic Archipelago islands, the CAE collected specimens of lake trout, fourhorn sculpin, Snow Goose, Stilt Sandpiper, and Sanderling, thus confirming the occurrence of these species in the area. The CAE collected numerous specimens of a diversity of species in Bernard Harbour and neighbouring areas, Camden Bay area, Cape Kellett, and Walker Bay, localities that had not been included in earlier vertebrate records of species such as the Spectacled Eider, Dunlin, and red fox.

Despite the relatively low number of species inventoried by the CAE, the sample was fairly representative of the core western Arctic vertebrate community. Four fish orders, namely the Scorpaeniformes, Salmoniformes, Gadiformes, and Perciformes, accounted for $88.5 \%$ of the total number of species inventoried. They altogether dominate the Arctic marine ichthyofauna by the number of species (Eastman, 1997; Mecklenburg et al., 2013). Most of the birds inventoried were Anseriformes, Charadriiformes, and Passeriformes $(78.5 \%$ of the total number of species), and these three orders dominate the western Arctic avifauna (Ganter and Gaston, 2013; Payer et al., 2013). Similarly, the mammal sample, comprising mostly rodents, carnivores, and a few ungulates ( $88.5 \%$ of the total number of species), fairly portrayed the western Arctic dominant groups.

By comparison, during the Stefansson-Anderson Expedition of 1908-12, Anderson collected 825 vertebrate specimens for the $\mathrm{AMNH}$, in addition to 170 bird eggs. He then travelled through an area similar to that of the southern party in Canada: from Point Barrow, Alaska, east to the middle portion of Coronation Gulf and southern Victoria Island (Anderson, 1913). In the late 19th and early 20th centuries, the GSC launched several Arctic expeditions of lesser or greater scope (Zaslow, 1975), among which was the Neptune Expedition of 1903-04, a major undertaking 
and, in the view of the Dominion of Canada, a crucial expedition (Low, 1906; Bernier, 1910; Ross, 1976). This expedition to northern Hudson Bay was led by Albert P. Low (Caron, 1965), geologist of the GSC, with several scientists on board. With the contribution of the determined naturalist Andrew Halkett, they collected 320 birds and mammals (mostly birds) and inventoried 41 species. The National Museum of Natural History of the Smithsonian in Washington, D.C. made extensive collections of natural history specimens from the Arctic, including some in Canada (Levere, 2004). This institution sent great collectors in the second half of the 19th century, including Robert Kennicott and Constantin Drexler, and later in the early 20th century, Edward A. Preble. These three naturalists collected altogether 1718 vertebrate specimens of about 230 species, mostly birds (73\%), from the North American Arctic over a period of 55 years (1860 to 1914). The area they prospected encompassed much of the Canadian mainland Arctic, with Kennicott and Preble collecting in the Mackenzie and Keewatin districts and Drexler around James Bay in the lower Arctic. This larger area, encompassing also regions of higher productivity and species diversity adjacent to the boreal biome, would account for the higher number of species these collectors inventoried. The Crocker Land Expedition, led by Donald B. MacMillan between 1913 and 1917 (MacMillan, 1918), was not as productive as had been anticipated, at least in botany and zoology. Two sets of eggs of the Red Knot (Calidris canutus) and 60 marine teleost fish, most of which were collected by M.C. Tanquery, zoologist of the expedition, were brought back from the northwest coast of Greenland (MacMillan, 1918; Nichols, 1918).

In sum, until the CAE returned home, only Franklin's expeditions could compare to the CAE with regard to natural history (Anderson, 1918; Anonymous, 1920). Sir John Richardson, a surgeon and naturalist, embarked with John Franklin on two overland expeditions (1819-22 and $1825-27$ ) to the northern coast of mainland Canada (Houston, 1983, 1984). Three outstanding volumes on vertebrates resulted from his two expeditions. Assisted by W. Swainson, Richardson produced the most comprehensive, reliable accounts of Arctic mammals, birds, and fishes of those times (Richardson, 1829, 1836; Swainson and Richardson, 1831).

Seventy-four scientific and technical reports were derived from the CAE and published in 13 volumes between 1919 and 1946. They dealt with topics of geology, geography, zoology, botany, and ethnology. Anderson was appointed general editor of these reports. Stefansson, in addition, publicized the CAE widely in the 1920s and later, particularly in his publically acclaimed book, The Friendly Arctic (Stefansson, 1921). This narrative, however, was not acknowledged as an official report by the government of Canada, even though Canada's Prime Minister, Sir Robert Borden, wrote its introduction. Anderson drafted many manuscripts consisting of accounts of CAE travel events and achievements progressively made in geology, topography, and natural history (CMN archives). He was also to report on the mammals and birds (Volume II, parts $\mathrm{A}$ and $\mathrm{B}$ ). He spent some time at the Smithsonian and the AMNH, comparing the specimens he had collected to the type specimens in the two museums' collections. He later informed Wilkins, in a letter he wrote on 17 March 1920 (Anderson, 1920), that he was about to complete the technical notes on the species. However, none of his aforementioned manuscripts dealt specifically with the CAE mammals and birds, and none of those technical notes he mentioned to Wilkins seemed to have ever been completed either. His duties related to the publication of the CAE reports and his position within the GSC were so demanding that he could barely spare some time to write up his reports (Anderson's notes at the CMN archives). Ten years after returning from the Arctic (ca. 1926), Johansen drafted a manuscript on the fish, which he did not publish. Walters (1953) later examined Johansen's manuscript and listed the CAE fish. Wilkins was no scientist. Nonetheless, he reported some basic field observations on vertebrates he made on Banks Island and the vicinity in a publication (Wilkins, 1918) and also produced some unpublished, rudimentary reports dealing with different topics, including one on the birds observed and collected on Banks Island from summer 1914 to summer 1916 (Wilkins, n.d.) and one on mammals (Anderson's notes at the CMN archives). Thus, no full report has ever been published on the fish, birds, and mammals, despite the fact that they were a major component of the CAE's natural history objectives.

The CAE's mineral, plant, and animal specimens were a significant supplement to Canada's early geological and natural history collections. At the CMN, they also prompted a major collection development (Khidas, 2013). Almost all the fish are preserved in ethanol or formalin, and for some, skulls and otoliths were also kept. The birds are preserved in the form of study skins; in addition, 140 nest and egg sets were collected. The mammals are preserved either as study skins or as skeletal parts (mostly skulls), or both; a very few are also preserved in ethanol.

Natural history collections are the source of invaluable raw data that serve many scientific, historical, educational, and inspirational purposes. Specimens from museum collections and their associated data are used in various fields, including biology, environment monitoring, agriculture, veterinary medicine, human health, and forensic science (Chapman, 2005). They enable scientists to address numerous questions and make significant scientific advances. And their importance as a potential source of new information continues to grow as new technologies emerge. The collections amassed by the CAE a century ago have been used in many research and educational programs ever since.

\section{ACKNOWLEDGEMENTS}

The author is indebted to Chantal Dussault, head of the CMN Library and archives, and Ted Sypniewski, CMN acquisitions and serials officer, who pulled together a long list of documents related to the Canadian Arctic Expedition 1913-18, along with 
Anderson's numerous notes, draft reports, published matters, and press clips archived at the CMN; and to William Tait for his advice on further readings. Brian Coad, Noel Alfonso, Michel Gosselin, and Jordan Mallon (CMN) willingly reviewed a first draft. Comments and criticisms of anonymous referees improved the manuscript.

\section{REFERENCES}

The American Ornithologists' Union. 2014. Checklist of North and Middle American birds, 7th ed. http://checklist.aou.org/

Anderson, R.M. 1913. Report of the natural history collections of the expedition. In: Stefansson, V. My life with the Eskimo. New York: The Macmillan Company. 436-527.

1917. Recent explorations on the Canadian Arctic coast. Geographical Review 4(4):241 - 266. http://dx.doi.org/10.2307/207437

- 1918. The Canadian Arctic Expedition of 1913: Report of the Southern division. Report of the Department of the Naval Service for the fiscal year ending March 31, 1917. Sessional paper 38:28-64.

- 1920. Letter of 17 March 1920 to G.H. Wilkins. CMNAC/1996-077 Series A - R.M. Anderson, Box 70, File 48. Ottawa: Canadian Museum of Nature Archives.

1942. Two new seals from Arctic Canada with key to the Canadian forms of hair seals (family Phocidae). Quebec: Annual Report of Provancher Society of Natural History of Canada. 23-47.

- 1943. Summary of the large wolves of Canada, with description of three new Arctic races. Journal of Mammalogy 24(3):386-393.

http://dx.doi.org/10.2307/1374839

Anonymous. 1920. Report of the Canadian Arctic Expedition, 1913 - 18. Scientific books review. Science 51(1311):167- 169. http://dx.doi.org/10.1126/science.51.1311.167

Bartlett, R.A., and Hale, R.T. 1916. The last voyage of the Karluk: Flagship of Vilhjalmar Stefansson's Canadian Arctic Expedition of 1913-16. Toronto: McClelland, Goodchild \& Stewart.

Bernier, J.E. 1910. Report on the Dominion Government Expedition to the Arctic Islands and the Hudson Strait on board the D.G.S. 'Arctic.' Ottawa: Government Printing Bureau.

Boudreau, R. 1913. Certified copy of the report number 406 of the Committee of the Privy Council approved by his Royal Highness the Governor General on 22 February 1913. CMNAC/1992-001 B - R.M. Anderson, Box 19, File 231.

Brock, R.W. 1913. Letter of 4 June 1913 to R.M. Anderson. CMNAC/1992-001 B - R.M. Anderson, Box 19, File 231. Ottawa: Canadian Museum of Nature Archives.

Caron, F. 1965. Albert Peter Low et l'exploration du QuébecLabrador. Cahiers de géographie du Québec, 9(18):169-182. http://dx.doi.org/10.7202/020595ar

Chapman, A.D. 2005. Uses of primary species-occurrence data, version 1.0. Report for the Global Biodiversity Information Facility. Copenhagen: GBIF.
Clarke, C.H.D. 1954. Wildlife research in the North American Arctic. Arctic 7(3-4):255-265.

http://dx.doi.org/10.14430/arctic3853

Cook, F.R., Coad, B.W., Renaud, C.B., Gruchy, C.G., and Alfonso, N.R. 2010. Donald Evan McAllister, 1934-2001: The growth of ichthyological research at the National Museum of Canada/ Canadian Museum of Nature. Canadian Field-Naturalist 124(4):330-335.

Desbarats, G.J. 1913. Letter of 29 May 1913 to V. Stefansson. CMNAC/1992-001 B - R.M. Anderson, Box 19, File 231. Ottawa: Canadian Museum of Nature Archives.

Diubaldo, R.J. 1978. Stefansson and the Canadian Arctic. Montreal: McGill-Queen's University Press.

Eastman, J.T. 1997. Comparison of the Antarctic and Arctic fish faunas. Cybium 21(4):335-352.

Froese, R., and Pauly, D., eds. 2015. FishBase. www.fishbase.org

Ganter, B., and Gaston, A.J. 2013. Chapter 4: Birds. In: Meltofte, H., ed. Arctic biodiversity assessment: Status and trends in Arctic biodiversity. Akureyri, Iceland: Conservation of Arctic Flora and Fauna. 143-180.

Godfrey, W.E. 1986. The birds of Canada, rev. ed. Ottawa: National Museum of Natural Sciences, National Museums of Canada.

Hewitt, C.G. 1920. List of new genera and new species of Insects, Arachnids and Myriapods collected by the Canadian Arctic Expedition, 1913-18. Report of the Canadian Arctic Expedition 1913-18. Volume III: Insects. Ottawa: Department of Mines.

Houston, C.S. 1983. John Richardson (1787-1865). Arctic 36(4):376-377.

http://dx.doi.org/10.14430/arctic2296

— surgeon-naturalist with Franklin, 1820-1822. Montreal: McGill-Queen's University Press.

Jenness, S.E. 2011. Stefansson, Dr. Anderson and the Canadian Arctic Expedition, 1913-1918: A story of exploration, science and sovereignty. Mercury Series, History Paper 56. Gatineau: Canadian Museum of Civilization Corporation.

Khidas, K. 2013. La collection de mammifères du Musée canadien de la nature: $100^{\mathrm{e}}$ anniversaire en 2012. Le Naturaliste canadien 137(1):45-50. http://dx.doi.org/10.7202/1013189ar

Levere, T.H. 1988. Science and the Canadian Arctic, 1818-76, from Sir John Ross to Sir George Strong Nares. Arctic 41(2):127-137. http://dx.doi.org/10.14430/arctic1704

- 2004. Science and the Canadian Arctic: A century of exploration 1818-1918. Cambridge: Cambridge University Press.

Low, A.P. 1906. Report on the Dominion government expedition to Hudson Bay and the Arctic islands on board the D.G.S. Neptune 1903 - 1904. Ottawa: Government Printing Bureau.

MacMillan, D.B. 1918. Four years in the white North. New York and London: Harper \& Brothers Publishers.

Macoun, J., and Macoun, J.M. 1909. Catalogue of Canadian birds. Ottawa: Canada Department of Mines, Geological Survey Branch, Government Printing Bureau. 
Mathias, J. 2013. The Canadian Beaufort Sea ecosystem: A fisheries perspective. Canada/Inuvialuit Fisheries Joint Management Committee Report 2013-01. 111 p.

Mecklenburg, C.W., Byrkjedal, I., Christiansen, J.S., Karamushko, O.V., Lynghammar, A., and Møller, P.R. 2013. List of marine fishes of the Arctic region annotated with common names and zoogeographic characterizations. Akureyri, Iceland: Conservation of Arctic Flora and Fauna.

Mirsky, J. 1970. To the Arctic! The story of northern exploration from earliest times. Chicago: The University of Chicago Press.

Mueter, F.J., Reist, J.D., Majewski, A.R., Sawatzky, C.D., Christiansen, J.S., Hedges, K.J., Coad, B.W., et al. 2013. Marine fishes of the Arctic. Arctic Report Card: Update for 2013. Washington, D.C.: National Oceanic and Atmospheric Administration. 58-72.

http://www.arctic.noaa.gov/report13/marine fish.html

Naughton, D. 2012. The natural history of Canadian mammals. Ottawa and Toronto: Canadian Museum of Nature and University of Toronto Press.

Naval Service. 1915. Patrol of northern waters. Report of the Department of Naval Service for the fiscal year ending March 31, 1914. Sessional paper 38:12-14.

-. 1916. Canadian Arctic Expedition. Report of the Department of Naval Service for the fiscal year ending March 31, 1915. Sessional paper 38:12-18.

-. 1917. Canadian Arctic Expedition. Report of the Department of Naval Service for the fiscal year ending March 31, 1916. Sessional paper 38:16-19.

- 1919. Canadian Arctic Expedition. Report of the Department of Naval Service for the fiscal year ending March 31, 1918. Sessional paper 38:18-31.

Nelson, E.W. 1934. New subspecies of the American Arctic hare. Proceedings of the Biological Society of Washington 47:83 - 86 .

Nichols, J.T. 1918. Some marine fishes from northwest Greenland. Bulletin of the American Museum of Natural History $38: 677-683$.

Noice, H. 1924. With Stefansson in the Arctic. New York: Dodd, Mead \& Company.

Norcross, B.L., Holladay, B.A., Busby, M.S., and Mier, K.L. 2010. Demersal and larval fish assemblages in the Chukchi Sea. Deep-Sea Research Part II 57(1-2):57-70.

http://dx.doi.org/10.1016/j.dsr2.2009.08.006

Page, L.M., Espinosa-Pérez, H., Findley, L.T., Gilbert, C.R., Lea, R.N., Mandrak, N.E., Mayden, R.L., and Nelson, J.S. 2013. Common and scientific names of fishes from the United States, Canada, and Mexico, 7th ed. Special Publication 34. Bethesda, Maryland: American Fisheries Society.

Payer, D.C., Josefson, A.B., and Fjeldså, J. 2013. Species diversity in the Arctic. Chapter 2. In: Meltofte, H., ed. Arctic biodiversity assessment: Status and trends in Arctic biodiversity. Akureyri, Iceland: Conservation of Arctic Flora and Fauna. 67-77.

Reid, D.G., Berteaux, D., and Laidre, K.L. 2013. Mammals. Chapter 3. In: Meltofte, H., ed. Arctic biodiversity assessment. Status and trends in Arctic biodiversity. Akureyri, Iceland: Conservation of Arctic Flora and Fauna. 79-141.

Reshetnikov, Y.S. 2004. Coregonid fishes in Arctic waters. Annales Zoologici Fennici 41:3-11.
Richardson, J. 1829. Fauna Boreali-Americana; or the zoology of the northern parts of British America: Containing descriptions of the objects of natural history collected on the late northern land expeditions, under command of Captain Sir John Franklin, R.N. Part first, containing the quadrupeds. London: John Murray.

- 1836. Fauna Boreali-Americana, or the zoology of the northern parts of British America: Containing descriptions of the objects of natural history collected on the late northern land expeditions, under command of Captain Sir John Franklin, R.N. Part third: The fish. London: R. Bentley.

Ross, W.G. 1976. Canadian sovereignty in the Arctic: The Neptune Expedition of 1903-04. Arctic 29(2):87-104.

http://dx.doi.org/10.14430/arctic2794

Schledermann, P. 2003. The Muskox Patrol: High Arctic sovereignty revisited. Arctic 56(1):101-106. http://dx.doi.org/10.14430/arctic606

Soper, J.D. 1962. In memorium: Rudolph Martin Anderson 1876-1961. The Canadian Field-Naturalist 76(3):127-133.

Stefansson, V. 1913. My life with the Eskimo. New York: The Macmillan Company.

- 1919. Solving the problem of the Arctic. Part I. Harper's Magazine 138:577-590.

— 1921. The friendly Arctic: The story of five years in polar regions. New York: The Macmillan Company.

Swainson, W., and Richardson, J. 1831. Fauna BorealiAmericana, or the zoology of the northern parts of British America: Containing descriptions of the objects of natural history collected on the late northern land expeditions, under command of Captain Sir John Franklin, R.N. Part second: The birds. London: J. Murray.

Walters, V. 1953. The fishes collected by the Canadian Arctic Expedition, 1913 - 18, with additional notes on the ichthyofauna of western Arctic Canada. Annual Report of the National Museum for the Fiscal Year 1951-52, Bulletin of the National Museum of Canada 128:1-18.

- 1955. Fishes of western Arctic America and eastern Arctic Siberia: Taxonomy and zoogeography. Bulletin of the American Museum of Natural History 106:257-368.

Wilkins, G.H. 1918. Report on topographical and geographical work. Part III. Report of the Department of the Naval Service for the fiscal year ending March 31, 1917. Sessional paper 38:65-70.

- n.d. Report of George H. Wilkins on birds observed and collected on Banks Island, Arctic Ocean, in 1914, 1915, 1916. Canadian Arctic Expedition of 1913-16. CMNAC/1996-077 Series A - R.M. Anderson, Box 70, File 49. Ottawa: Canadian Museum of Nature Archives.

Wilson, D.E., and Reeder, D.M., eds. 2005. Mammal species of the World: A taxonomic and geographic reference, 3rd ed. Baltimore, Maryland: Johns Hopkins University Press.

WoRMS Editorial Board. 2015. WoRMS: World register of marine species. http://www.marinespecies.org

Zaslow, M. 1975. Reading the rocks: The story of the Geological Survey of Canada, 1842-1972. Toronto, Ontario: Macmillan Company of Canada. 